\title{
PENGATURAN DAN PELAKSANAAN PENGELOLAAN PERPARKIRAN KOTA
}

\section{Oleh :}

\section{Indrati Rini}

\begin{abstract}
As one of local retribution's sources, the handling of parking affair should be seriously concerned. Up till now, the regulations has not yet been implemented as expected. There are still many regulation infractions by private sector and even by local government itself. Therefore, the office of parking affair should pay more attention and initiate more effective coordination among related offices, due to the achievement of local retributions revenue.
\end{abstract}

Keywords : Private sector, local retributions.

\section{PENDAHULUAN}

Seperti kita ketahui bahwa sektor perparkiran merupakan sektor yang menyentuh kehidupan rakyat banyak, termasuk rakyat perkotaan. Jasa perparkiran di satu sisi sebagai sumber aset daerah, di sisi lain sebagai mata pencaharian sejumlah anggota masyarakat.

Pengelolaan perparkiran daerah belumlah menampakkan timbulnya ketaatan hukum, baik oleh pihak pengelola, juru parkir, dan masyarakat pengguna jasa parkir. Mereka belum sepenuhnya sadar hukum. Pelanggaran-pelanggaran perparkiran terjadi tanpa dapat dikontrol dan diatasi oleh instansi terkait, terutama Dinas Perparkiran Daerah.

Hasil dari sektor parkir, tidak selamanya dapat dinikmati dan masuk ke Kas Daerah. Berbagai kebocoran ditemui di lahan-lahan perparkiran, baik yang dikelola Pemerintah Daerah atau Swasta. Oleh karena itu, perlu dianalisis sejauh mana tertib hukum pengelolaan perparkiran dilaksanakan dalam menunjang pendapatan dan pembangunan daerah.

Parkir dapat dianggap sebagai suatu perjanjian (agreement, verbintennis), yang melibatkan dua pihak atau lebih untuk saling memberikan prestasinya. Dalam hal ini parkir dapat disebut sebagai perjanjian timbal balik atau perjanjian bilateral.

Perjanjian timbal balik atau bilateraal contract is one of each party receives as consideration for promise from the other party (G.B. Lowe, 1983). Para pihak yaitu pengelola/juru parkir dan pengguna jasa parkir yang saling memberikan prestasinya.

Parkir tergolong sebagai perjanjian untuk 
memberikan sesuatu, yang lebih spesifik lagi merupakan campuran (mixed agreement) antara perjanjian penitipan barang dan sewa menyewa pelataran parkir. Oleh karena itu perjanjian parkir merupakan perjanjian konsensuil, yaitu dianggap sah dan mngikat setelah adanya kata sepakat kedua belah pihak (pasal 1548 dan pasal 1320 Kitab UndangUndang Hukum Perdata).

Dalam perjanjian parkir, sebenarnya terdapat unsur penyerahan barang/kendaraan bermotor kepada juru parkir, dengan maksud untuk dijaga atau diawasi keamanannya. Selanjutnya, jika pemilik kendaraan akan mengambil barangnya, maka juru parkir harus menyerahkan kembali barangnya dalam wujud utuh seperti semula. Di sisi lain, pengelola/juru parkir berhak menerima pembayaran parkir berupa sejumlah uang sebagaimana yang ditentukan dalam karcis parkir, karena pengelola/juru parkir telah menyediakan jasanya untuk mengawasi/menjaga kendaraan sebaik-baiknya, hal ini sebagai indikasi bahwa parkir merupakan perjanjian penitipan barang.

Dalam parkir ada juga indikasi bahwa pengelola atau juru parkir berkewajiban memberikan kenikmatan untuk memakai lahan parkir, sehingga membuktikan parkir sebagai perjanjian sewamenyewa lahan/pelataran parkir yaitu tanah/gedung sebagai barang tidak bergerak, yang diimbangi pembayaran karcis parkir oleh pengguna parkir.

Dalam membicarakan retribusi parkir, tentunya tidak dapat dilepaskan dari keberadaan pajak (tax). Hal ini disebabkan baik pajak maupun retribusi merupakan iuran, yang kedua-duanya berfungsi sebagai aset atau sumber pendapatan negara/daerah.

"Tax is a compulsory constribution from the person, to the Government to defray the expences incurred in the common interest of all, without reference to special benefit conferred" (Edwin RA. Seligman, 1979).

Oleh karena itu, pajak sebagai iuran rakyat kepada negara untuk membiayai kepentingan umum, tanpa prestasi timbal yang bersifat langsung kepada rakyat, namun rakyat akan memperoleh pelayanan atau fasilitas-fasilitas umum dari Pemerintah.

Selanjutnya, retribusi juga merupakan iuran atau pembayaran oleh rakyat kepada pemerintah, namun prestasi timbalnya bersifat langsung, yaitu dapat dinikmatinya fasilitas pelataran parkir. Prestasi ini memang disengaja sebab pembayaran tersebut memang ditujukan semata-mata oleh pembayar retribusi untuk mendapat suatu prestasi dari pemerintah.

Berdasarkan data yang ada di Dinas Perparkiran Kotamadya Surabaya, retribusi KMS diperoleh antara lain dari pasar, PDAM, rumah potong hewan, sampah, iklan atau reklame, terminal, IMB, Puskesmas, kependudukan ataupun perparkiran.

Penyelenggaraan dan pengelolaan urusan lalu lintas dan angkutan jalan merupakan kegiatan yang kompleks, meliputi volume kegiatan dan permasalahan yang cukup besar, dengan jumlah kendaraan yang beraneka ragam, maka salah satu dinas yang 
dibutuhkan adalah Dinas Perparkiran Daerah. Dinas Perparkiran Daerah Kotamadya Tingkat II Surabaya dibentuk berdasarkan Perda No. 15 Tahun 1995 tentang pembentukan, Organisasi dan Tata Kerja Dinas Perparkiran Daerah. Dinas Perparkiran adalah unsur pelaksana pemerintah daerah di bidang parkir, yang tugasnya meliputi penunjukan dan pengelolaan parkir kendaraan bermotor dan tidak bermotor.

Agar tugas-tugas Dinas Perparkiran dapat dilaksanakan dengan baik, maka dinas ini juga mempunyai fungsi-fungsi perencanaan, pelaksanaan, penatausahaan, koordinasi, dan pengawasan, yang kesemuanya ini dipimpin oleh kepala Dinas Perparkiran yang langsung di bawah Walikotamadya Kepala Daerah.

Kepala Dinas Perparkiran dibantu secara organisatoris oleh Kepala Sub Bagian Tata Usaha dan Seksi-seksi, yang meliputi Seksi Pendapatan, Seksi Parkir Umum, Seksi Parkir Khusus, Seksi Pengawasan, Penyidikan, serta kelompok Jabatan Fungsional.

Dalam melaksanakan tugasnya, Kepala Perparkiran harus berdasarkan kerbijaksanaan yang ditetapkan Walikotamadya Kepala Daerah, serta harus melaksanakan prinsip-prinsip koordinasi, integrasi, sinkronisasi dan simplikasi, baik di lingkungan dinas maupun dengan instansi-instansi lain di luar dinas.

Pengelolaan lahan dan retribusi parkir di
Surabaya berdasarkan Perda No. 3 Tahun 1995 yang diperbarui dengan Perda No. 19 Tahun 1998.

Mengenai cara parkir ditentukan bahwa setiap pemakai parkir harus memarkir kendaraannya di tempat-tempat parkir yang ditunjuk oleh petugas parkir, sesuai dengan lahan parkir di tepi jalan umum, di temapt parkir, gedung atau pelataran parkir.

Di dalam tata tertib Parkir ditentukan bahwa setiap pemakai tempat parkir dilarang parkir di luar batas suatu petak parkir, merintangi kebebasan ke luar masuknya kendaraan lain, atau menyebabkan terganggunya kelancaran lalu lintas. Dalam hal ini petugas parkir berwenang memerintahkan kepada pemarkir di luar tempat parkir, agar masuk tempat parkir yang telah disediakan.

Tarif untuk retribusi parkir digolongkan berdasarkan lahan parkir dan jenis kendaraan, yaitu tempat parkir umum, tempat parkir khusus yang dikelola swasta atau Pemda, di antaranya Terminal Angkutan Umum, dan tempat parkir insidentil. Tarif parkir, misalnya untuk sekali parkir bagi truck Rp. 1.500 (Parkir Umum), mobil sedan Rp 500 (Parkir Khusus), pick up dan truck mini Rp. 600 untuk dua jam pertama (terminal), sepeda motor Rp. 200 (parkir insidentil).

Retribusi parkir yang dikelola pleh pihak lain selain Pemda, yaitu Swasta dapat dilaksanakan dengan memungut pembayaran, dan pungutan tersebut sebesar-besarnya sama dengan tarif parkir, sebagaimana yang dikelola Pemda. Namun dalam 
prakteknya, banyak terjadi penyimpangan, di mana tarif parkir swasta melebihi jumlah yang ditetapkan Pemda, misalnya untuk parkir mobil seharusnya Rp. 500, tapi ditarik Rp. 1.000 untuk sekali parkir.

Ketentuan-ketentuan parkir dalam pelaksanaannya sangatlah bervariasi, dari satu lokasi ke lokasi parkir yang lain, terutama parkir yang dikelola pihak swasta. Ketentuan-ketentuan yang beragam tersebut lazimnya dapat diketahui secara tertulis di masing-masing karcis parkir, baik di bagian depan maupun belakang.

Ketentuan parkir dapat ditemui, misalnya "segala bentuk kerusakan/kehilangan kendaraan atau barangbarang di dalamnya, sepenuhnya menjadi tanggung jawab pemilik" (Karcis Parkir, Jembatan Merah Plaza). Dalam hal ini, pengelola/jukir akan terlepas dari tanggung jawabnya jika kendaraan hilang, sebaliknya pemilik kendaraan jarang menyadari ketentuan ini, akibatnya menjadi pihak yang dirugikan.

Selanjutnya ditemukan ketentuan parkir, yaitu "Kendaraan harus dikunci, kehilangan, kerusakan barang menjadi tanggung jawab pemilik" (Karcis Parkir, Mitra Cineplex 21). Di sini betapa berat beban pemilik, sudah berkewajiban mengunci kendaraan, namun jika kendaraan hilang atau rusak, tak dapat menuntut apapun juga, karena pengelola/jukir terlepas dari tanggung jawabnya.

Antara Parkir Swasta dan Parkir Pemda, memang terdapat perbedaan dalam pengelolaannya, diantaranya parkir Pemda harus menyetor hasil parkir kepada Dinas Perparkiran, sedangkan bagi parkir Swasta kewajiban ini tidak ada, sehingga hasil parkir disetor ke pengelolanya sendiri. Dahulu, ada kewajiban penyetoran bagi parkir swasta sebesar $30 \%$ - $35 \%$ dari hasil parkir selama 1 bulan, namun dengan adanya Undang-undang No. 18 Tahun 1997 dan Instruksi Menteri Dalam Negeri No. 10 Tahun 1997 tentang Pencabutan Peraturan Daerah dan Retribusi Daerah, kewajiban penyetoran itu tidak berlaku lagi. Akibatnya, Pemerintah Daerah Kotamadya Surabaya kehilangan aset sebesar Rp. 18,7 milyar setiap bulannya (Kepala Sub Tata Usaha Dinas Perparkiran Surabaya, 1999).

Sebelum membicarakan penyimpangan, ada baiknya melihat kondisi para jukir di lapangan, karena boleh jadi sebagai penyebab terjadinya penyimpangan di lapangan.

Para jukir sebagian besar, yaitu hampir 95\% berasal dari Madura dan berpendidikan rata-rata Sekolah Dasar, bahkan sebagian ada yang buta huruf. Hal ini tentu saja sangat berpengaruh terhadap pola pikimya, antara lain "pendapatan sehari-hari biarpun pas-pasan, asalkan cukup untuk biaya hidup anakistri sehari-hari".

Para jukir pemda mempunyai kewajiban, di antaranya untuk menyetor sejumlah 15\%-40\% dari penghasilan perminggu/bulan ke petugas KMS. Dalam prakteknya, para jukir sering mbalelo/ingkar tidak menyetor, dengan berbagai alasan, diantaranya parkir sedang sepi, Petugas biasanya merasa iba dan 
memberikan kelonggaran, dengan imbalan diberikannya uang rokok/bensin pada petugas.

Untuk parkir swasta, keragaman penyimpangannya dapat dilihat, di antaranya tarif parkir yang lebih tinggi dari ketentuan, tidak diberikannya karcis, diberi karcis tetapi diminta kembali, dan berbagai pelanggaran lainnya. Di samping itu, di lapangan ditemui pula pengelolaan lahan parkir swasta secara turun-temurun, bermunculan parkir liar tak berijin, lahan bawah tanah, praktek Korupsi, Kolusi dan Nepotisme bahkan adanya mafia perparkiran.

Muara pengelolaan pendapatan parkir adalah pada Dinas Pendapatan Daerah, sebaiknya untuk pengelolaannya dapat diserahkan sepenuhnya sebagai tugas dan tanggung jawab Dinas Perparkiran. Pendapatan parkir swasta yang tidak lagi masuk Kas Daerah, mengurangi aset dan anggaran daerah, sehingga kesejahteraan petugaspun berkurang. Jumlah petugas/personil Dinas Perparkiran, yaitu 334 orang, yang sebagian besar berpendidikan SLTA, tak mampu mengimbangi jumlah lokasi parkir, yaitu 1394 lokasi, yang tersebar di Surabaya Utara, Timur Selatan, barat dan Pusat (Bio Data Dinas Perparkiran, 1999).

Selanjutnya para pengelola parkir swasta, karena diberi wewenang untuk mengatur sendiri, maka sulit sekali ditertibkan, sehingga tarif karcis parkir dan ketentuan-ketentuannya amatlah beragam. Sebaiknya, untuk parkir swasta dikembalikan pada kebijaksanaan lama, yaitu berkewajiban menyetor ke
Pemda dan tunduk pada ketentuan-ketentuan parkir Pemda, sehingga terdapat keseragaman secara menyeluruh di lapangan.

Masyarakat sebagai konsumen jasa perparkiran, pada akhirnya yang merasa terbebani, di antaranya pelepasan tanggung jawab pengelola/ jukir atas rusak/hilangnya kendaraan, tarif parkir yang mahal, ataupun parkir liar yang diragukan keamanannya.

Kesejahteraan petugas parkir KMS dan juru parkir haruslah menjadi prioritas utama. di samping itu pembinaan mental dan moral bagi mereka amatlah penting, sebab kondisi di lapangan memang amat memungkinkan terjadinya penyimpanganpenyimpangan. Di samping itu, para petugas dari instansi yang terkait, yaitu Dinas Pekerjaan Umum, Polisi Lalu Lintas, DLLAJR dengan Dinas Perparkiran, utamanya para pengelola/jukir mengkatkan kinerjanya, jujur, dan konsisten, sehingga akan terhindar dari perbuatan tercela di lapangan.

\section{PENUTUP}

Adanya perparkiran sebagai jasa yang sangat dibutuhkan masyarakat banyak, merupakan tanggung jawab kita bersama, tidak saja kesadaran dan kepatuhan hukum dari pengguna jasa parkir, tetapi juga para petugas terkait, menuju perparkiran yang bersih dan bermanfaat bagi pembangunan bangsa dan negara. 
Tertib hukum perparkiran daerah dapat terlaksana dengan baik, jika kontrol Dinas Perparkiran Daerah dilakukan secara kontinyu dengan sanksi yang tegas. Moral para petugas lapangan harus ditempa terus menerus, di samping diperhatikan pula peningkatan kesejahteraannya, sehingga pelanggaranpelanggaran perparkiran, terutama penerimaan retribusi parkir daerah yang didapatkan dari parkir tidak mengalami kebocoran.

Kas Daerah dengan adanya tertib retribusi parkir, merupakan modal yang kuat dalam upaya membantu pemasukan pendapatan daerah agar digunakan untuk membangun daerah yang aman dan sejahtera.

\section{DAFTAR PUSTAKA}

Anderson and Kumf, Business Law, "Contractual Capacity", South Western Publishing Co., 1976.

Badan Pembinaan Hukum Nasional Departemen Kehakiman, Simposium Aspek Hukum Perlindungan Konsumen, Bina Cipta, Jakarta, 1986.

Cohen, Morris, Legal Research, West Company, Minnesotta, 1988.

Indrati Rini, Perjanjian Baku Bali Sewa Kendaraan Bermotor di Jawa Timur, Disertasi, Universitas Airlangga, Surabaya, 1996. , Variasi Pelaksanaan ketentuanketentuan Perparkiran Di Kotamadya
Daerah Tingkat II Surabaya, Universitas Bhayangkara, Surabaya, 1999.

Rochmat Sumitro, Hukum Pajak, Eresco, Bandung. 1980.

Soetojo Prawirohamidjojo, dan Marthalena Pohan, Hukum Perikatan, Bina Ilmu, Surabaya, 1979.

Soetandyo Wignjosoebroto, Hukum dan Metode Kajiannya, Fakultas Hukum, Universitas Airlangga, Surabaya, 1981.

\section{Satjipto Raharjo, Manfaat Telaah Sosial} Terhadap Hukum, Universitas Diponegoro, Semarang, 1980.

Peraturan Daerah Kotamadya Daerah Tingkat II Surabaya Nomor 3 tahun 1995 Tentang Perubahan Ketiga Perda Nomor 3 tahun 1985 Tentang Tarif retribusi Parkir Kendaraan Dalam Kotamadya Daerah Tingkat II Surabaya.

Peraturan Daerah Nomor 19 Tahun 1998 Tentang Pengelolaan Tempat dan Retribusi Parkir di Wilayah Tingkat II Surabaya.

Peraturan Daerah Nomor 15 Tahun 1996 Tentang Pembentukan Organisasi dan Tata Kerja Dinas Perparkiran Daerah Kotamadya Tingkat II Surabaya. 